\title{
Szansa na lepszą przyszłość. Edukacja dorosłych w systemie penitencjarnym Azji Środkowej
}

\author{
A chance for a better future. Adult education in the prison \\ system in Central Asia
}

Streszczenie. Dziś trudno zrozumieć, co doprowadziło człowieka do idei pozbawiania wolności: kara i zadawanie bólu, wykorzystywanie więźniów jako taniej siły roboczej czy resocjalizacja przestępcy. Jednak już w trzecim wieku jeden z najsłynniejszych rzymskich prawników napisał, że „więzienie powinno służyć jedynie jako miejsce zatrzymywania/przetrzymywania/pozbawienia wolności, ale nie karania". Wzorcowe reguły minimalne postępowania z więźniami Organizacji Narodów Zjednoczonych (ONZ) traktują osadzonych jako jednostki będące częścią tego samego społeczeństwa, które funkcjonuje poza murami instytucji penitencjarnych. Zgodnie z nimi powrót więźniów do życia w społeczeństwie powinien być łatwiejszy poprzez zapewnienie im możliwości edukacji, którą będzie można kontynuować także po wyjściu na wolność, uwolnieniu.

W ciągu ostatnich dziesięciu lat DVV International zgromadził bogate doświadczenie w dziedzinie kształcenia dorosłych w systemie penitencjarnym Azji Środkowej. Autorka niniejszego artykułu - Project Manager tych inicjatyw - opisuje działalność DVV International $\mathrm{w}$ dziedzinie edukacji dorosłych $\mathrm{w}$ systemie penitencjarnym na przykładzie trzech krajów Azji Środkowej: Uzbekistanu, Kirgistanu i Tadżykistanu. Artykuł zawiera podejścia/koncepcje, metody i wyniki tych działań.

Summary. Today it is hard to understand, what brought the human to the idea of imprisonment: punishment and hurting, use of convicted as cheap labour force or re-training of the violator. But in the $3^{\text {rd }}$ Century one of the famous Rome lawyers wrote: "The prison should serve as a place of imprisonment not as one of a punishment".

United Nations Standard Minimum Rules for the Treatment of Prisoners observes the convicted as personalities, being a part of the same society, which is existing outside penal institutions. Their return into the society's life should be facilitated by providing opportunities for education, which could be continued after the release. 


\section{4 | Tatiana Zaiczenko}

During the last ten days DVV International gathered rich experience in the field of adult learning in the penitentiary system of Central Asia. The Author of the present article, Project Manager of those initiatives, describes the activity of DVV International in the field of Adult Education in the Penitentiary system on the example of three countries of Central Asia: Uzbekistan, Kyrgyzstan and Tajikistan. The Article contains approaches, methods and result of these actions.

Człowiek i jego czyny to dwie różne sprawy. Chociaż dobry uczynek zasługuje na aprobatę, a zły na osąd, to człowiek czy dobry czy zły czyn popełnił, zawsze zasługuje na szacunek lub współczucie.

Mahatma Gandhi

Dziś trudno zrozumieć, co doprowadziło człowieka do idei pozbawiania wolności: kara i zadawanie bólu, wykorzystywanie więźniów jako taniej siły roboczej lub resocjalizacja przestępcy. Wszakże ludzi zaczęto zamykać do więzień dawno temu, gdy tylko człowiek nauczył się budować, cele i piwnice pojawiły się zarówno w pierwszych kamiennych budowlach w Egipcie, czy ceglanych w Mezopotamii, jaki i w królewskich fortecach oraz ogromnych zamkach baronów. Słowo „karcer”, z łaciny carcer oznacza więzienie, a od niego incarcerate - zamknąć do więzienia, pojawiło się w angielskich książkach prawnych/prawniczych napisanych około 890 roku naszej ery.

Jednak już w trzecim wieku jeden z najsłynniejszych rzymskich prawników napisał, że „więzienie powinno służyć jedynie jako miejsce zatrzymywania/przetrzymywania/pozbawienia wolności, ale nie karania”.

Wzorcowe reguły postępowania z więźniami Organizacji Narodów Zjednoczonych (ONZ) traktują osadzonych jako jednostki będące częścią tego samego społeczeństwa, które funkcjonuje poza murami instytucji penitencjarnych. Zgodnie z nimi powrót więźniów do życia w społeczeństwie powinien być łatwiejszy, poprzez zapewnienie im możliwości edukacji, którą będzie można kontynuować także po wyjściu na wolność, zwolnieniu.

W realizację tych zaleceń wpisuje się działalność DVV International ${ }^{1}-$ organizacji posiadającej bogate międzynarodowe doświadczenia w pracy na

1 Instytut Współpracy Międzynarodowej Niemieckiego Związku Uniwersytetów Ludowych. Na całym świecie DVV International współpracuje z ponad 200 partnerami w ponad 40 krajach Afryki, Azji, Ameryki Łacińskiej i Europy z gospodarką przejściową. W Azji Środkowej biura regionalne funkcjonują w Uzbekistanie, Kirgistanie, Tadżykistanie. DVV International postrzega siebie jako profesjonalnego partnera, który wnosi swoją wiedzę i doświadczenie do wspólnych projektów i skupia się na zrównoważonej współpracy z orga- 
polu edukacji dorosłych w systemie penitencjarnym, jak również z osobami, którzy wrócili do domu po odbyciu kary.

W dwóch krajach Azji Środkowej - Uzbekistanie i Kirgistanie już od kilku lat prowadzone są projekty dotyczące edukacji zawodowej skazanych, podwyższenia kwalifikacji pracowników zakładów karnych (nauczyciele szkół zawodowych i funkcjonariuszy/oficerów), psychologicznego i prawnego wsparcia zwolnionych. W 2014 roku podobny projekt przy finansowej pomocy Unii Europejskiej i współfinansowaniu ze strony Ministerstwa Współpracy Gospodarczej i Rozwoju (Bundesministerium Wirtschaftliche Zusammenarbeit und Entwicklung BMZ) Republiki Federalnej

Niemiec rozpocznie się w Republice Tadżykistanu.

\section{Uzbekistan}

W Uzbekistanie projekt rozpoczął się w 2003 roku i trwa do dzisiaj dzięki finansowej pomocy Ministerstwa Współpracy Gospodarczej i Rozwoju Republiki Federalnej Niemiec (BMZ).

$\mathrm{Na}$ początkowym etapie realizacji projektu grupę docelową stanowiły tylko skazane kobiety, spośród których wiele nie zdążyło na wolności otrzymać należytego wykształcenia, ani zawodu i posiadało niewielkie, negatywne lub w ogóle nie miało doświadczenia w uczeniu się, pracy w przemyśle, lub innego przygotowania do pracy zawodowej. Celem głównym projektu jest wsparcie dążenia skazanych do powrotu do wartościowego społecznie stylu życia poprzez przekwalifikowanie, kształcenie podstawowe skierowane na uzyskanie zawodu. Po przeprowadzeniu badania zostały określone kierunki, w których kobiety chciałyby się kształcić. Dodatkowo przy tworzeniu programów edukacji zawodowej skazanych kobiet brano pod uwagę: poziom posiadanej wiedzy ogólnej, wiek, specyfikę posiadanego doświadczenia zawodowego.

Przez lata realizacji projektu w zakładach karnych około tysiąca skazanych kształciło się na takich kursach zawodowych jak: Fryzjerstwo; Projektowanie, krój, szycie; Obsługa komputera, zdjęcia i montaż wideoklipów; Dziewiarstwo, Sztuka użytkowa (makrama, wytwarzanie ozdób z koralików,

nizacjami społecznymi i instytucjami państwowymi. Szczegółowe informacje na temat opisywanej organizacji i jej działalności znaleźć można na stronie: www.dvv-international.de $i$ www.dvv-international.uz. 
wytwarzanie wyrobów ze skóry, technika batik i inne); Cukiernictwo; Wytwarzanie wyrobów makaronowych.

W celu podniesienia efektywności kursów zakupiono: wyposażenie salonów fryzjerskich, sprzęt szwalniczy, aparaturę do wytwarzania wyrobów makaronowych, wyposażenie do klas komputerowych, aparaty fotograficzne, kamery wideo.

Głównym kryterium doboru uczestniczek kursów była zasada dobrowolności (niezależnie od tego, czy kobieta przygotowywała się do zwolnienia, czy odbywana przez nią kara trwać miała jeszcze długie lata). W proces edukacji kobiet zostali włączeni zaproszeni trenerzy i nauczyciele szkoły zawodowej, znajdującej się na terenie zakładu. Poszczególne bloki tematyczne prowadziły również same skazane posiadające dobre przygotowanie zawodowe $\mathrm{w}$ danym zakresie i wcześniejsze doświadczenie w nauczaniu (np. ze sztuki użytkowej, projektowania odzieży kobiecej). Uzyskanie nowych kwalifikacji zarówno dla skazanych uczących się, jak i dla tych, które nauczały, okazało się ważnym środkiem podnoszenia/podwyższania poczucia własnej wartości.

Stało się jasne, że główne zadanie nauczycieli biorących udział w projekcie, to stopniowe wszczepianie kobietom smaku artystycznego, ujawnienie ich potencjału twórczego. Kursy przygotowania zawodowego przyczyniły się do wciągnięcia tak niełatwej grupy, jaką są skazane, w proces edukacyjny, a także do stworzenia im warunków przystosowania się do nowych realiów życia po zwolnieniu. Jak pokazały przeprowadzone na bazie programów edukacyjnych badania, edukacja zawodowa ma ponadto istotny psychoterapeutyczny efekt: pomaga przywrócić umiejętności komunikacyjne, usuwa wewnętrzne bariery, rozwija sferę psychoemocjonalną.

Obecnie rozpoczęto prace dotyczące edukacji zawodowej, także w męskich zakładach.

Po zakończeniu każdego kursu zawodowego prowadzone są seminaria edukacyjne, szkolenia wsparcia psychologicznego, bloki arteterapii, które prowadzą zaproszeni specjaliści: lekarze, psychologowie, prawnicy, pracownicy struktur państwowych. Celem takich programów podniesienie wiary w siebie, we własne siły, w możliwość rozpoczęcia nowego życia po zwolnieniu. Formowanie umiejętności słuchania i słyszenia - to podstawowa funkcja tych seminariów. Omawiane są na nich zmiany, które zachodzą we współczesnym świecie, udzielane są porady na temat psychologii komunikacji, aby do społeczeństwa powracali ludzie, którzy będą mogli znaleźć swoje miejsce w życiu, naprawić/odbudować utracone więzi społeczne.

W czasie realizacji projektu ważna była ocena skuteczności podejmowanych wysiłków, poszukiwań metodycznych. Przeprowadzone badanie po- 
kazało, że dzięki uczestnictwu w kursach zawodowych i edukacyjnych 70\% skazanych miało nadzieję uzyskać zawód, 50\% - psychologicznie ułatwić sobie pobyt w zamknięciu, $40 \%$ - poczuć się bardziej pewnym siebie.

Skuteczność przeprowadzonych działań oceniana jest przez to, jak wygląda życie byłego skazańca po zwolnieniu. Powszechnie wiadomo, że odbywanie kary $\mathrm{w}$ formie pozbawienia wolności związane jest $\mathrm{z}$ szeregiem negatywnych czynników, które utrudniają ponowną adaptację do funkcjonowania w społeczeństwie: im dłuższy wyrok, tym trudniejszy jest ten proces. Życie zmienia się na tyle szybko, że ludzie, którzy spędzili kilka lat w zamknięciu, po zwolnieniu trafiają $\mathrm{w}$ zupełnie nowe środowisko: $\mathrm{z}$ nowymi prawami, innym poziomem życia, zmienionymi wartościami społecznymi. Jest jeszcze jeden problem - przez lata przebywania w miejscach odbywania kary człowiek nabywa infantylności społecznej - poszukiwać pracy nie trzeba, zapracować na jedzenie i ubranie także nie jest konieczne, wszelkie problemy rozwiązywane są przez zakład. Stąd niska motywacja do proszenia o pomoc, słabe umiejętności komunikacyjne i strach przed zwróceniem się do jakichkolwiek oficjalnych struktur i organizacji, brak wiedzy o dostępnych rodzajach wsparcia, brak wprawy w ubieganiu się o wsparcie.

W 2012 roku, jedna ze zwolnionych kobiet, wygrała w konkursie małych grantów ogłoszonym przez Przedstawicielstwo DVV International (obecnie Filia DVV w Uzbekistanie) wykazawszy możliwości pracy z określoną grupą docelową - byłymi pensjonariuszkami zakładu karnego. Dzięki jej inicjatywie i dobrej znajomości sytuacji, zostały przeprowadzone seminaria dla zwolnionych kobiet pod tytułem „Życie trwa dalej”, w którym uczestniczyli prawnicy, psychologowie, przedstawiciele struktur państwowych. Biorąc pod uwagę występowanie specyficznej kategorii zwolnionych (inwalidzi, kobiety, mające małoletnie dzieci; ludzie w wieku przedemerytalnym i emerytalnym) zaproszeni specjaliści przekazali informację o istnieniu prawnych ulg, dotacji, przywilejów dla tej grupy osób. Dla kobiet pojawiła się możliwość omówienia interesujących je problemów, wymiany pozytywnym doświadczeniem adaptacyjnym. W 2013 roku ideę tę podchwyciła jedna z pozarządowych organizacji i zorganizowała program psychologicznego i prawnego wsparcia kobiet, włączając w proces realizacji tego przedsięwzięcia przedstawicieli struktur państwowych, bez których rozwiązanie szeregu problemów byłoby niemożliwe.

Drugim zadaniem projektu było podniesienie kwalifikacji personelu instytucji penitencjarnych (nauczycieli szkół zawodowych i ogólnokształcących oraz funkcjonariuszy). Praca w nich wymaga unikalnej kombinacji cech osobowościowych i umiejętności technicznych. Pracownik powinien posia- 


\section{8 | Tatiana Zaiczenko}

dać cechy charakterologiczne, które pozwalają na obiektywne, humanitarne i sprawiedliwe traktowanie wszystkich skazanych, w tym trudnych i niebezpiecznych. Zwiększenie kwalifikacji personelu zostało przeprowadzone $\mathrm{z}$ użyciem skutecznych współczesnych metod uczenia (się) ludzi dorosłych. Komponent metodyczny edukacji, włączający omówienie kwestii związanych z wykorzystaniem tej lub innej metody lub techniki pracy, pozwolif uczestnikom rozszerzyć zasoby narzędzi pracy. W tym celu zostały zorganizowane seminaria edukacyjne: „Metody pracy z dorosłymi”, „Główne kierunki edukacji dorosłych w systemie penitencjarnym”, „Podstawy psychologii penitencjarnej. Rys psychologiczny skazanych”, „Współczesne metody diagnostyki i korekcji stanu psychoemocjonalnego skazanych”, „Zawodowo-etyczne zasady i normy w pracy pracowników systemu penitencjarnego". Dodatkowo dla naczelników zakładów penitencjarnych został zorganizowany wyjazd do Brandenburgii (RFN) w celu wymiany doświadczeń.

\section{Kirgistan}

System penitencjarny w Republice Kirgiskiej boryka się z tym samym zestawem problemów, z którymi zmagają się analogiczne systemy w krajach zniszczonych po rozpadzie Związku Radzieckiego: niedostateczne zabezpieczenie materialne, zawiłość podziału i kontroli społeczeństwa więziennego, niedostateczne wykształcenie personelu więziennego i brak możliwości jego uzupełniania zgodnie z wymogami współczesnego systemu penitencjarnego.

Od marca 2012 roku w Kirgistanie dzięki pomocy finansowej Unii Europejskiej w ramach linii programowej: „Wsparcie reformy systemu penitencjarnego w Republice Kirgiskiej”, rozpoczęła się realizacja projektu »SZANSA“ (Edukacja dorosłych w systemie penitencjarnym: szansa na lepszą przyszłość).

Projekt ten jest realizowany przez DVV International w partnerstwie z Kirgiskim Towarzystwem Edukacji Dorosłych (KAOB) w dwóch pilotażowych szkołach zawodowych trzech zakładów penitencjarnych. Projekt ma przyczynić się do procesu liberalizacji systemu penitencjarnego dzięki edukacji dorosłych, wspierać procesy rehabilitacji skazanych do życia w społeczeństwie dzięki możliwości zdobycia wykształcenia zawodowo-technicznego, zdobycie doświadczenia praktycznego i rozszerzenia kompetencji pracowników w zakładach pilotażowych.

Projektem zostało objętych około dwustu skazanych - to kobiety i mężczyźni w różnym wieku, o różnym statusie społecznym. Ponadto pro- 
jekt objął sześćdziesięciu trenerów i instruktorów nauki pięciu zawodów, dwudziestu psychologów, zastępców dyrektorów i naczelników pododdziałów systemu karnego.

W ramach projektu został wzmocniony potencjał techniczny szkół zawodowych, odremontowano pomieszczenia klasowe i pracownie, zakupiono i zainstalowano nowoczesny sprzęt do praktycznej nauki zawodu. W 2013 roku edukacja zawodowa skazanych dotyczyła zawodów, na które było zapotrzebowanie zarówno w zakładach, gdzie rozwija się produkcja, jak również na rynku pracy: Elektryk do naprawy sprzętu elektrycznego, Wypalacz cegieł, Piekarz, Szwaczka, Krawiec, Operator maszyny do szycia, Spawacz.

Opinia jednego ze skazanych: $W$ ciągu pót roku przywykłem do nauki. Wstaję rano i wiem, że trzeba iść do szkoły, przychodzę, uczę się, wytapiam metal. Można nawet powiedzieć, że odpoczywam od świata przestępczego. Projekt ten to realna szansa na nowe życie dla każdego z nas!

Szczególne wrażenie wywarła, towarzyszącą otwarciu pomieszczeń klasowych i pracowni, prezentacja odzieży uszytej przez osadzone, która odbyła się w żeńskim więzieniu w sierpniu 2013 roku. W prezentacji uczestniczyły kobiety, które za względu na okoliczności nie mogą codziennie tulić swoich dzieci, kupić kosmetyków lub sukienki, która im się podoba, uczesać się w salonie fryzjerskim, nakryć stołu dla swojej rodziny. Ale one nie zapomniały, że są kobietami. $Z$ godnością i wdziękiem prezentowały nowoczesne modele, uszyte własnymi rękami, z dumą zademonstrowały, jak umiejętnie pracują na nowoczesnym sprzęcie.

Jeden z pracowników zakładu powiedział: Jest u nas jedna kobieta, skazana za zabójstwo. Ma 42 lata. To jej pierwsza odsiadka. Jak trafita do zakładu, załamała ręce. Każdego dnia rozmawialiśmy i zaczęła chodzić na kursy. Tutaj po raz pierwszy usiadła przy maszynie do szycia. Teraz opowiada, że jest to takie interesujące, a wcześniej nigdy nie trzymała igły i nitki w ręku. Teraz zaczęła się zastanawiać nad otwarciem własnej działalności po zwolnieniu.

Wszystkim uczestnikom grup projektowych zostały wręczone certyfikaty, na które naprawdę zasłużyli, i które w przyszłości, taka jest nadzieja, pomogą im łatwiej znaleźć pracę.

W toku rozmów ze skazanymi okazało się, że zarówno kobiety, jak i mężczyźni chcieliby, aby szkoły zawodowe uzupełniły swoją ofertę edukacyjną o nowe kierunki, takie jak:

d) wszystkie rodzaje nowoczesnego remontu (gładź szpachlowa, płyta gipsowo-kartonowa, panele podłogowe, podwieszane sufity itp.),

e) ocieplenie pomieszczeń (ocieplenie ścian, ogrzewanie podłogowe),

f) sztukateria elewacyjna, 
g) obsługa komputera,

h) rzemiosło ludowe,

i) kursy dla salonów kosmetycznych (makijaż, pedicure, manicure, kursy fryzjerskie).

Oprócz szkolenia zawodowego, w ramach projektu prowadzone były kursy dotyczące rozwoju umiejętności życiowych skazanych, które okazały się nie mniej popularne. Skazani otrzymali wiedzę, niezbędną zarówno do życia w zakładach karnych, jak również po zwolnieniu, otrzymali wsparcie psychologiczne, informacje dotyczące: prawodawstwa, poszukiwania pracy, przygotowania dokumentów, rejestracji w charakterze bezrobotnych itd.

Szczególną uwagę przywiązywano do podniesienia kwalifikacji nauczycieli i trenerów edukacji przygotowującej do pracy w przemyśle. Przeprowadzone zostały szkolenia, na których uczono nowoczesnych metod nauczania dorosłych i technologii produkcji. W rezultacie zostały opracowane i wprowadzone do procesu edukacyjnego modułowe programy szkoleniowe z kilku specjalizacji.

Pracownicy systemu penitencjarnego wzięli udział w programach edukacyjnych z „Podstaw psychologii penitencjarnej. Rys psychologiczny skazanych". W wyniku seminariów dwóch psychologów zostało wybranych do uczestnictwa w VI Środkowoazjatyckiej Letniej Akademii, zorganizowanej przez DVV International na temat: „Aspekty psychologiczne edukacji dorosłych" i teraz opracowują własne moduły pracy ze skazanymi z arteterapii i umiejętności życiowych.

Znaczenie tego projektu dla kraju zostało potwierdzone wręczeniem jego kierownikowi medalu „Ustat” (Mistrz) za sukcesy w jego realizacji. Medal ten został ustanowiony przez Państwową Służbę Więzienną przy Rządzie Republiki Kirgiskiej. Przyznanie medalu uzasadniono znaczącym wkładem w rozwój organów i instytucji systemu karnego Republiki Kirgiskiej oraz za szczególne zasługi w udzieleniu pomocy w wykonaniu zadań powierzonych Państwowej Służbie Więziennej przy Rządzie Republiki Kirgiskiej.

\section{Tadżyistan}

Przedstawicielstwo Unii Europejskiej w Tadżykistanie poprało nowy projekt pod nazwą „SECRET: Społeczno-ekonomiczne i kulturowe prawa więźniów i byłych więźniów w Tadżykistanie” w ramach Programu „Europejska inicjatywa na rzecz Demokracji i Praw Człowieka" (EIDHR) stworzonego w oparciu o Krajowy Model Wsparcia (CBSS) dla Tadżykistanu. Projekt został 
opracowany i będzie wdrażany od 2014 roku przez 24 miesięcy przez DVV International wspólnie $\mathrm{z}$ dwoma miejscowymi partnerami - organizacjami społecznymi - Biurem praw człowieka i przestrzegania prawa i «Dzhahon», aby przyczynić się do rozwoju i umocnienia demokracji i praworządności, podstawowych praw i wolności w Tadżykistanie poprzez poprawę dostępu do edukacji i rozwoju osobistego dla więźniów i byłych więźniów - zarówno kobiet, jak i mężczyzn.

\section{Wnioski}

Zakłady karne w zaprezentowanych krajach Azji Środkowej posiadają zróżnicowane i niejednoznaczne doświadczenie na gruncie przygotowania zawodowego skazanych. Ale nie ma wątpliwości, że edukacja daje skazanym dodatkową możliwość pozostania sobą w warunkach izolacji od społeczeństwa, przyczynia się do rozwoju zdolności i umiejętności zawodowych, sprzyja zmniejszeniu antyspołecznych zachowań uczących się, zwiększa szansę na udaną resocjalizację, a więc zmniejsza prawdopodobieństwo recydywy.

W Rezolucji 1990/20 Rady Ekonomicznej i Społecznej ONZ mówi się o edukacji w więzieniach w następujących słowach:

a) edukacja w więzieniu powinna być ukierunkowana na rozwój jednostki jako całości, z uwzględnieniem poziomu społecznego, ekonomicznego i przygotowania kulturalnego osadzonych;

b) wszyscy osadzeni powinni mieć dostęp do edukacji, przygotowania zawodowego, twórczego zajęcia, religijnej i kulturalnej działalności, wychowania fizycznego i sportu, wychowania społecznego, wyższego wykształcenia i usług bibliotecznych.

Ale system penitencjarny powinien jeszcze rozwiązać kilka ważnych problemów związanych ze zwiększeniem różnorodności zawodów, rozwojem produkcji, wprowadzeniem do kursów przygotowania zawodowego bloków z rozwijania umiejętności życiowych, zwiększeniem skuteczności pracy z zakresu doradztwa zawodowego, wyposażeniem pomieszczeń klasowych i pracowni.

\section{Podstawowe zasady postępowania z osadzonymi. Zasada 8}

„Konieczne jest tworzenie warunków, dających osadzonym możliwość znalezienia dobrze płatnej pracy, co ułatwi ich ponowną integrację na krajowym 
rynku pracy i zobowiąże do udzielania finansowej pomocy swoim rodzinom i krewnym".

Edukacja - to centralny element w systemie rehabilitacji społecznej skazanych. W programach edukacyjnych skierowanych do skazanych konieczne jest uwzględnianie specyficznych cech każdego człowieka, zapewnienie możliwości ogólnego rozwoju kulturalnego. $Z$ reguły osoby po zwolnieniu spotykają się z problemem zatrudnienia, a w zakładach penitencjarnych uwidacznia się oderwanie od normalnego trybu życia, brak perspektyw życiowych i możliwości zmiany czegokolwiek. Podniesienie statusu społecznego każdego człowieka - skazanego, zwolnionego - pociąga za sobą zmiany w zachowaniu, buduje wiarę w swoje siły, a przede wszystkim prowadzi do zrozumienia tego, że podejmowanie wysiłków prowadzi do sukcesu zarówno w poszukiwaniu pracy, jak i w rozwiązywaniu istotnych życiowo zadań.

W trakcie pracy z systemem penitencjarnym zebrano doświadczenia, z których można wyciągnąć następujące wnioski:

- Przed rozpoczęciem pracy dla systemu penitencjarnego należy bardzo dokładnie przeanalizować krajowe przepisy (konstytucję kraju, ustawę o edukacji, kodeks karny, regulamin odwiedzin zakładu).

- Przeanalizować właściwości systemu penitencjarnego nie tylko swojego kraju, ale także innych dla porównania.

- Poznać terminy, które są akceptowane w rozmowach z personelem i skazanymi.

- Ważnym elementem pracy jest zapewnienie dostępu do instytucji. Konieczne jest uzyskanie zgody od władz, dlatego należy zwrócić się do wyższych władz z pismem, w którym przedstawiony zostanie cel pracy i prośba o wyrażenie zgody. Powinny zostać w nim opisane korzyści, które może przynieść taka działalność.

- Konieczna jest umowa z ministerstwem o wspólnej działalności, gdzie jasno zostaną określone prawa i obowiązki obu stron.

- Każdy, kto zaczyna pracę w systemie penitencjarnych instytucji, powinien posiadać doświadczenie pracy z różnymi grupami docelowymi, w tym z uzależnionymi od narkotyków, zarażonymi wirusem HIV i innymi grupami ryzyka.

- Uważnie przeanalizować potrzeby instytucji, w których prowadzona jest praca (nie tylko potrzeby skazanych, ale i personelu).

- Obowiązkowo pracować z personelem (nie tylko z funkcjonariuszami, ale także nauczycielami szkół ogólnokształcących lub szkół zawodowych, jeżeli takowe są). 
- Jeżeli w kraju są placówki edukacyjne, które przygotowują personel do systemu penitencjarnego, należy postarać się wykorzystać i ten zasób.

- Poznawszy pracę szkoły, szkoły zawodowej w instytucji penitencjarnych, zaproponować zaproszenie trenerów, nowe programy.

Z języka rosyjskiego przetłumaczyła Kinga Majchrzak 